\title{
Judging the twelve tribes of Israel: Q 22:28, 30 in light of the Psalms of Solomon and the Community Rule
}

\author{
Author: \\ Llewellyn Howes ${ }^{1}$ \\ Affiliation: \\ ${ }^{1}$ Department of Religion \\ Studies, University of \\ Johannesburg, South Africa \\ Correspondence to: \\ Llewellyn Howes \\ Email: \\ Ilewellynhowes@gmail.com \\ Postal address: \\ 1 Dormus, 281 Acacia Street, \\ Blackheath 2195, \\ South Africa \\ Dates: \\ Received: 12 Dec. 2013 \\ Accepted: 10 May 2014 \\ Published: 30 Sept. 2014 \\ How to cite this article: \\ Howes, L., 2014, 'Judging \\ the twelve tribes of Israel: \\ Q 22:28, 30 in light of the \\ Psalms of Solomon and the \\ Community Rule', Verbum \\ et Ecclesia 35(1), Art. \#1320, \\ 11 pages. http://dx.doi. \\ org/10.4102/ve.v35i1.1320

\section{Copyright:} \\ (C) 2014. The Authors. \\ Licensee: AOSIS \\ OpenJournals. This work \\ is licensed under the \\ Creative Commons \\ Attribution License.
}

Read online:

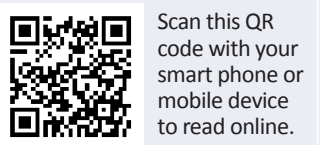

The current article considers two intertexts of Q 22:28, 30, namely the Psalms of Solomon and the Community Rule found in the first Qumran cave. Each of these documents is examined to understand its view of the restoration of Israel, the messianic age, the apocalyptic end and the final judgement. Additional attention is paid to the way in which these documents draw boundaries around their respective in-groups. By illustrating that these texts foresaw a process of judgement at the apocalyptic end that would entail both the liberation and the condemnation of greater Israel, the current article argues against the popular claim that a wholesale liberation of everyone in Israel was expected during the Second-Temple period. The broader context of this investigation is the attempted refutation of Horsley's influential

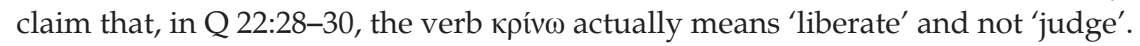

Intradisciplinary and/or interdisciplinary implications: By illustrating that these texts foresaw a process of judgement at the apocalyptic end that would entail both the liberation and the condemnation of greater Israel, the current article argues against the popular claim that a wholesale liberation of everyone in Israel was expected during the Second-Temple period.

\section{Introduction \\ Horsley's influential ${ }^{1}$ proposal}

Q 22:28, 30 (Mt 19:28 and Lk 22:28, 30) reads as follows: 'You who have followed me will sit on

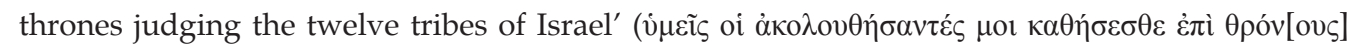

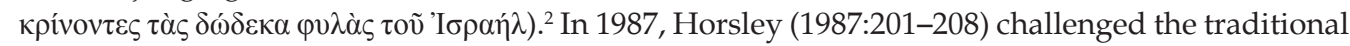

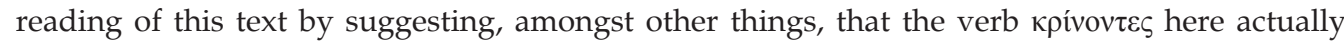
means 'liberating', 'redeeming' or 'effecting justice for' instead of 'judging' or 'ruling'. The implication of his lexical shift is a profound hermeneutical shift in the reading of this $\mathrm{Q}$ logion. Instead of declaring that the twelve tribes of Israel will one day be judged by the followers of Jesus, the logion now states that the followers of Jesus will do their part in effecting justice for the twelve tribes of Israel. According to Horsley (1999:105), this saying 'has been one of the key proof texts that Q proclaims judgement against all Israel' (cf. also Horsley 1989:49, 1995:39). This may indeed be true, but the opposite is also true. Horsley uses (his rendition of) this logion consistently as a proof text for his own conviction that $Q$ envisages the restoration and renewal of Israel. ${ }^{3}$ Horsley's specific reading of Q 22:28-304 forms part of his larger case that the ministry of the historical Jesus was aimed at the restoration and renewal of Israel (see Horsley 1987:165-284, 1992:175, 198-199, 206-209, 2003:79-104, 2011, esp. 205-211). Naturally, this does not invalidate his proposal, but it does show that he has much at stake in his exegesis of this logion. ${ }^{5}$

Horsley supports his understanding of $\kappa$ ív $\omega$ in Q 22:28, 30 with three basic arguments. Attention is, firstly, directed to the article by Herntrich (1965:923-933) in the Theological

1.Horsley's proposed reading of $Q 22: 28-30$ has been adopted by a number of influential historical Jesus, $Q$ and New Testament scholars, including Kaylor (1994:187), Davies and Allison (1997:55, esp. n. 119), Allison (1998:142) and Van Aarde (2011:1, n. 3).

2.Greek text and English translation derive from the reconstruction put forward by the International Q Project in the Critical Edition of $Q$ (see Robinson, Hoffmann \& Kloppenborg 2000)

3.The following quotations should suffice as verification (emphasis was added by the author - LH): (1) 'Even apart from the key text of Matthew 19:28 and parallels, there appears to be solid evidence that the 12 disciples were symbolic of the restoration of the twelve tribes of Israel' (Horsley 1987:200), (2) 'Matthew 19:28 and Luke 22:28-30 then provide explicit evidence that Jesus was symbolizing
the restoration of Israel in constituting the Twelve' (Horsley 1987:201), (3) 'If it had not been stated explicitly earlier in the document, this statement about the twelve tribes [in Q 22:28-30] makes abundantly clear that Q represents Jesus and his followers as engaged in the renewal of the people of Israel' (Horsley 1992:198), (4) 'If anything, based on a more appropriate reading of Q 22:28-30, in the renewal of the people of Israel' (Horsley 1992:198), (4) 'If
$Q$ envisages a renewal or restoration of Israel' (Horsley 1995:39).

4.In this article, I stay true to the numbering of $Q$ as reflected by the secondary authors in question, thereby reproducing ' $Q 22: 28-30$ ' when certain authors do so but also reproducing ' $Q$ 22:28, 30' when other authors do so. Regarding my own references to this text, the latter option is preferred.

5.In this regard, the following quotation from Horsley (1987:206) is very telling: 'The principal point to be derived from Matthew 19:28 and Luke 22:30, of course, is that, whether in the already-present reality of the kingdom or in the imminent completion of the kingdom's realization, [the historical] Jesus is concerned with the restoration or renewal of the people of Israel, as symbolized during his ministry in the constitution of the twelve disciples. 
Dictionary of the New Testament where it is persuasively argued that the Old Testament concept of 'judgement' (מִשְָּׁט) at times connoted and/or denoted God's (mediated) acts of liberation and salvation towards Israel (see Horsley 1987:203-205). Secondly, Horsley (1987:205-206) claims that his version and interpretation of $Q$ 22:28-30 fits the literary context of $\mathrm{Q}$ much better. Thirdly, Horsley (1987:205) directs attention to two intertextual examples, namely the Psalm of Solomon 17:26-30a $a^{6}$ and the Community Rule (or 1QS) 8:1-4 discovered in the first Qumran cave. ${ }^{7}$ I contested Horsley's first two arguments at some length elsewhere (see Howes 2014). In the current article, I wish to conclude my case against Horsley by considering his third argument. The two intertexts used by him as proof texts read as follows:

intertexts used by him as proof texts read as follows:

He will gather a holy people whom he will lead in righteousness; and he will judge the tribes of the people that have been made holy by the Lord their God. ${ }^{8}$

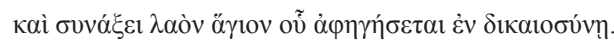

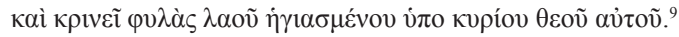
(Ps Sol 17:26-30a)

In the Community Council [there shall be] twelve men and three priests, perfect in everything that has been revealed about all the law to implement truth, justice, judgment, compassionate love and unassuming behaviour of each person to his fellow to preserve faithfulness on the earth with firm purpose and repentant spirit in order to atone for sin, doing justice and undergoing trials in order to walk with everyone in the measure of truth and the regulation of time. ${ }^{10}$

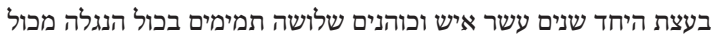

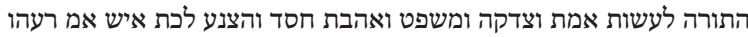

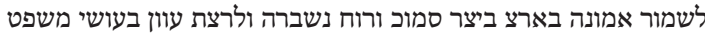

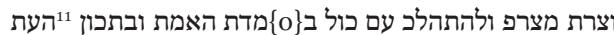

(1QS 8:1-4)

\section{The Psalms of Solomon Group boundaries}

Two distinctions are made by the Psalms of Solomon. Like most Jewish writings, a clear line is, firstly, drawn between Israel and the gentiles (Wright 1985:645). Like most sectarian writings, the second distinction creates a division within Israel itself, between the faithful and the

6.The original Greek and Syriac manuscripts do not have verse numbers. In the process of translation, the Syriac and Greek versions received different verse numbers.
Horsley's verse numbering $(17: 28)$ follows translations of the Syriac versions. Since this article follows the original Greek text (see footnote below), it also follows the verse numbering of the Greek translations.

7.For the sake of convenience, the fragments from cave 4 are not brought into the current discussion. This does not imply that the present author devalues their significance. Rather, the purpose of this article is mainly to refute Horsley, who only made use of $1 Q S$.

8.In the current article, all translations of the Psalms of Solomon derive from the translation proffered by Wright (1985:651-670).

9.This article follows the original Greek text. Although there is some disagreement about the value of the Syriac version of the Psalms of Solomon (see Trafton 1986:227-237), the Greek version is in all probability closer to the original (Wright 1985:640, cf. Atkinson 1998:100). At any rate, the divergences between the two versions are generally very slight, mostly having no real impact on the meaning.

10.In this article, unless stipulated otherwise, the translations of Qumran texts derive from García Martínez (1994)

11.The Hebrew text was taken from Abegg (2004:30) unfaithful (Atkinson 1998:108; Nickelsburg 2005:244). From a group-identity viewpoint, both distinctions function to demarcate the in-group from the out-group. Furthermore, each of the four groups has both a general and a specific reference. Regarding the first distinction, the in-group constitutes all of Israel, but more specifically, it has in mind the people of Jerusalem (Atkinson 1998:107). Jerusalem is clearly representative of Israel in toto. Besides opening the corpus of Psalms by having Jerusalem herself address the audience (1:1-8), the author commonly refers to this in-group in the first person plural but also sometimes refers to it as the 'children of Jerusalem' (oi vioì ' I $\varepsilon \rho 0 v \sigma \alpha \lambda \eta \mu$ ). Israel and the children of Jerusalem are accused of being ignorant of their own unrighteousness (1:1-8), acting without mercy, truth, righteousness or justice $(17: 15,19)$, arrogance and self-exaltation (1:4-6), committing $\sin$ in secret $(1: 7 ; 8: 9)$, being more unlawful than the gentiles $(1: 8 ; 8: 13 ; 17: 19)$, profaning Jerusalem and the temple $(1: 8 ; 2: 3 ; 8: 12,22)$, defiling the sacrificial offerings $(2: 3 ; 8: 12)$, stealing from the temple $(8: 11)$, failing to listen to $\operatorname{God}(2: 8)$, condoning prostitution $(2: 11,13)$, committing incest and adultery (8:9-10), and adopting pagan practices (17:15). These accusations apply to both the citizens and the leaders of Jerusalem (17:20; Collins 1998:143; De Jonge 1991a:9). On the other side of the coin, the out-group

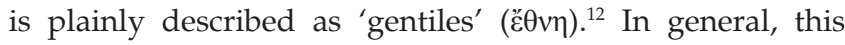
group represents all non-Jews, but more specifically, it has in mind the Romans under Pompey (e.g. Trafton 1986:227, 2006:427-428). They are accused of desecrating and defiling Jerusalem and the temple $(2: 2 ; 8: 22 ; 17: 14)$, insulting and ridiculing Jerusalem and her citizens $(2: 11,19-23)$, plundering the citizens of Jerusalem (2:24), killing and deporting the inhabitants of Jerusalem $(8: 20 ; 17: 11-12)$, arrogance $(2: 25$, $28-29,31 ; 17: 13)$, lawlessness $(17: 11)$ and causing syncretism in Israel (17:15).

Regarding the second distinction, the out-group is variously

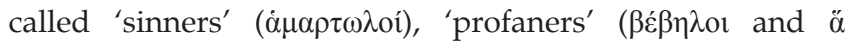

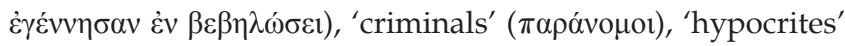
( this group is made up of all the stubbornly sinful Jews in both Palestine and the Diaspora (17:20; Collins 1998:143; De Jonge 1991a:9). It is also possible, though, that this group specifically constitutes the Jewish rulers who usurped the legitimate monarchy and priesthood in Jerusalem $(17: 5-8,22)$. Although it is not entirely certain, a number of scholars claim that these usurpers should be identified with the Hasmonean government (De Jonge 1991a:9; Nickelsburg 2005:242; Trafton 2006:428; Wright 1985:640, 642; contra e.g. Atkinson 1998:104-107). Besides violently overthrowing the monarchy, these sinners are accused of forgetting God (4:21; 14:7), being arrogant, verbose and ostentatious (4:2), angering and provoking God (4:21), committing sin in secret $(4: 5)$, living in hypocrisy $(4: 3,6,12)$, putting on a charade to impress and defraud others $(4: 7-8,19-20,22)$, breaking the Torah $(4: 1,12)$, being deliberately deceitful and dishonest $(4: 4,8-11 ; 12: 1-6 ; 17: 15)$, condoning and supporting

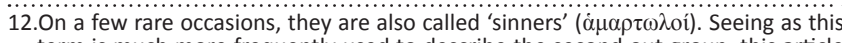
term is much more frequently used to describe the second out-group, this article prefers not to use it in reference to the Romans. 
prostitution (4:5), ogling women (4:4), being more lawless and impure than the gentiles $(2: 12 ; 4: 3 ; 8: 13 ; 14: 6 ; 15: 8)$, refusing to learn from God's chastisement (3:9-12) and passing cruel verdicts and harsh sentences (4:1-3).

Finally, the in-group of the second distinction is called

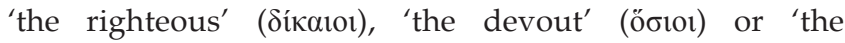
innocent' (ökakol). They are particularly described as displaying 'uprightness of heart' ( $\varepsilon \dot{v} \theta 0 \varsigma \tau \eta \tau 1 ~ \kappa \alpha \rho \delta i ́ \alpha \varsigma)$

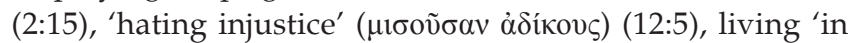

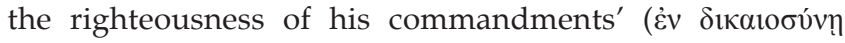

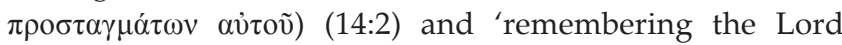
all the time by acknowledging and proving the Lord's judgment right' (3:3; cf. also 6:1). This group is characterised as relatively innocent, refraining from the habitual and careless committing of $\sin$ and doing penance for the occasional sins that do occur (e.g. Wright 1985:644-645). ${ }^{13}$ In general, this group incorporates all faithful, observant and pure Jews in both Palestine and the Diaspora (Embry 2002:121). More specifically, this group represents a specific faction of Jews who were deeply dissatisfied with the reigning leadership and the political status quo $(2: 14,22-23$; 17:4-5; Collins 1998:143-144). A number of suggestions have been made regarding the historical identity of this group, including Pharisaism, Essenism and 'Chasidimism' (De Jonge 1991a:5, 16-17, n. 5; Trafton 2006:428-434). At the moment, it might be best to simply consider the Psalms of Solomon to be 'the product of an unknown Jewish sect' (Atkinson 1998:112). One thing seems clear, though: the ingroup somehow shared in, or had a firm relationship with, former leadership before the latter were pushed out by the Hasmoneans (17:4-5).

\section{Final judgement}

Much more important for our purposes than the identification of these groups within history is the expected fates of each group. In the past, God punished Israel through the Assyrian and Babylonian exiles, which led to the dispersion of Israel amongst the nations (9:1-2). In the present, God makes use of the Romans to punish the children of Jerusalem and to expose the 'sinners' for their transgressions. ${ }^{14}$ Although the 'devout' support God's choice in punishing Israel, they feel that enough is enough (2:22; Wright 1985:643-644). They fear that Israel might be completely destroyed unless God censures the gentiles (2:23; Atkinson 1998:102). The Romans should, in their view at some stage be made to answer for their sins against God and his people (Wright 1985:653, n. 2w). God has already started punishing the Romans by causing the shameful death of Pompey, who did not even have a proper burial due to the manner in which he died (2:26-37; De Jonge 1991a:8; Nickelsburg 2005:239; Wright 1985:653, n. 2e $\mathrm{e}^{2}$ ). Despite this glimpse of retribution, still more is expected by the devout. They implore God to put an end to Roman occupation and to punish the gentiles for their sin and arrogance (2:22-25; $8: 30 ; 9: 8-11)$. That these hopes pertain not only to Rome 13.Cf. $3: 6-8 ; 4: 23 ; 6: 1-2 ; 8: 23 ; 9: 6-7 ; 10: 1-4 ; 12: 4 ; 13: 7-10 ; 14: 1 ; 16: 7-11 ; 18: 4$. but also to all foreign nations is indicated by 8:23: 'God was proven right in his condemnation of the nations of the earth' (cf. 17:3). ${ }^{15}$

Another reason why the devout beseech God to bring an end to Roman occupation is that the righteous do not believe that they deserve to be punished with the sinners (7:1-10; Wright 1985:644). There is an obvious overlap between the two in-groups, which leads to internal contradictions throughout the Psalms between corporate guilt and individual innocence (Nickelsburg 2005:239). ${ }^{16}$ The 'devout' still see themselves as part of Israel, but at the same time, they distinguish themselves from the 'sinners'. This leads to an interesting dynamic when it comes to their understanding of sin, guilt and punishment. As part of Israel, the 'devout' share in the sins of their forefathers as well as in the sins of their fellow countrymen. ${ }^{17}$ This corporate guilt explains the fact that they are sharing in the various punishments of God. In contrast, the 'devout' also believe in individual innocence and guilt. ${ }^{18}$ Although they corporately share in the guilt of Israel, they simultaneously proclaim themselves to be innocent and guilt-free. The devout therefore feel that they are somewhat unfairly sharing in God's punishment of Israel. They make sense of the status quo by explaining that God is using the Romans not only to punish the sinners but also to discipline and test the righteous (Nickelsburg 2005:238, 243; Wright 1985:643, 644). ${ }^{19}$ However, they believe that the current state of affairs will be resolved when God turns his judgement towards Israel.

Whilst terminating Roman occupation and punishing the gentiles, God will turn to Israel itself and 'separate between the righteous and the sinner' (

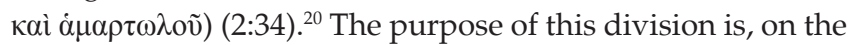
one hand, 'to repay sinners forever according to their actions'

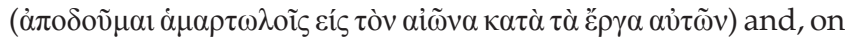
the other, 'to have mercy on the righteous [by keeping him] from

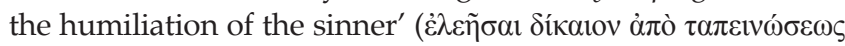
$\dot{\alpha} \mu \alpha \rho \tau \omega \lambda \mathrm{ov})$ (2:34-35; cf. Pr 24:16-22). The sinner is specifically

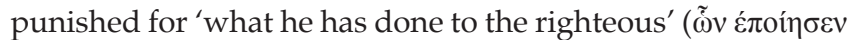
$\delta$ ¿кaí $(2: 35)$ whilst the righteous is specifically rewarded for 'persistently calling upon [God]' (

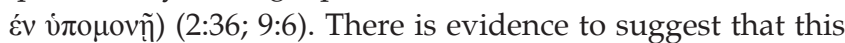
division is preordained $(15: 6,9 ; 18: 10-12)$. Nevertheless, this partition is the culminating result of the deeds of each individual and household in Israel (Nickelsburg 2005:239, 240; Wright 1985:645). ${ }^{21}$ There is a definite finality to God's expected judgement (Nickelsburg 2005:244). ${ }^{22}$ The fate of the 15.Although 5:15 states: 'Lord, your mercy is upon the whole world in goodness.'

16.By the way, there is also an obvious overlap between the first in-group (Jerusalem and Israel) and the second out-group (the sinners).

17.Cf. 8:25-26, 29, 32; 17:5, 15.

18.Cf. $2: 34 ; 5: 4 ; 8: 23 ; 9: 5 ; 17: 8-9$.

19.Cf. $3: 4 ; 7: 9 ; 14: 1 ; 16: 11,14$.

20.Cf. 4:6-25; 6:6; 10:3; 12:4; 13:2-3, 6, 11; 14:1, 9-10.

21.Cf. $2: 34 ; 5: 4 ; 9: 5 ; 17: 8-9$.

22.Cf. 3:11-12; 8:33-34; 9:11; 10:8; 11:9; 12:6; 13:11; 14:3-4; 15:12. 
sinners is that their sins will be exposed (4:7) and that they will be 'driven out from the presence of the righteous' ( $\dot{\varepsilon} v \tau \tilde{\varphi}$

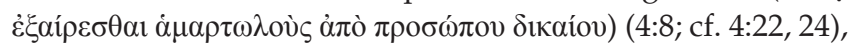
experiencing destruction, disgrace, anxiety, pain, poverty, failure, famine and childlessness for the rest of their lives and their children's lives before finally missing out on the general resurrection. ${ }^{23}$ Instead of one day rising with the devout,

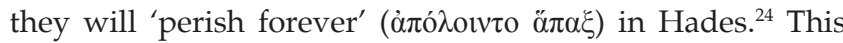
process of punishment had already begun with the capture of Jerusalem by the Romans, which included the execution and deportation of some of her citizens and leaders (Wright $1985: 639,659$, n. 8 p). ${ }^{25}$

Throughout the document, the everlasting mercy of God is reserved for the righteous (Trafton 2006:435). ${ }^{26}$ The end result of God's judgement is the restoration of Israel in this world (e.g. Collins 1998:143). In other words, restoration ${ }^{27}$ happens not through the liberation of all Israel but through the purification of all Israel (Embry 2002:109, 113, 118, 132-135). This process of purification includes the liberation of some and the punishment of others. In a word, the restoration of Israel entails weeding out the bad elements, including both gentiles and 'sinners', whilst repairing the faithful. Renovation of the devout will include not only the ingathering of the (innocent) Diaspora but also the reinstatement of the legitimate Davidic monarchy. ${ }^{28}$ The new messianic king will play a significant role in effecting God's plan to condemn both gentiles and Jewish sinners (17:22-25). Through this process of purification, the author wishes that ' $[\text { the remnant of }]^{29}$ Israel be

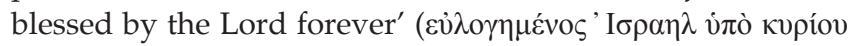

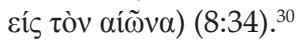

After dispensing judgement, gathering in the Diaspora and restoring the throne of David, God will reinstate the (twelve) tribes of Israel and distribute them evenly across the Promised Land (17:26, 28, 43-44). Not only the tribes of old but also the nations throughout the world will serve the new Davidic king and come under his rule forever (17:30). Nations will visit the king from all over the world just to witness his majesty and experience the glory of God (17:31). The messianic king and all his subjects will be completely holy and righteous (17:32$34,36)$. They will live by the Torah forever in the Lord's paradise (14:1-5). The reason why all Jews will be perfectly holy is that the new king will keep them in line by refusing to tolerate any form of unrighteousness (17:27). Even after the inauguration of the new dispensation, the king will still 'purge

23.сf. $4: 6,14-20 ; 13: 2-3,6,11 ; 14: 6-7,9 ; 15: 7-13 ; 16: 2,5$.

24.Cf. $12: 6 ; 14: 9 ; 15: 10-13 ; 16: 2$.

25.Cf. $2: 6-10 ; 8: 14-26 ; 17: 7-10$.

26.Cf. $2: 33-36 ; 4: 25 ; 5: 2,12 ; 6: 6 ; 7: 6,10 ; 8: 27 ; 9: 8 ; 10: 3-4,13: 12 ; 14: 9 ; 15: 13 ; 16: 3$, 6, $15 ; 17: 45$

27.Cf. the title of Psalm 7.

\section{Cf. 8:28; 11:1-9; 17:21, 31}

29.Cf. specifically the previous verse where only the devout and their descendents are in view, not the 'sinners'. The same applies to the contexts of 10:7-8 and 12:6. That mercy is particularly reserved for the remnant of Israel is made obvious by $17: 45$ See further the arguments of Atkinson (1998:109-110) that those responsible for the Psalms of Solomon did not represent greater Israel but were a strictly sectarian Synagogue community.

30.Cf. 9:8-11; 10:5-8; 11:8-9; 12:6; 17:45; 18:1-3.

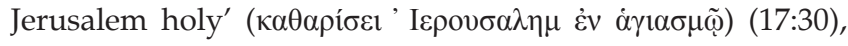
discipline the house of Israel (17:42) and 'expose officials

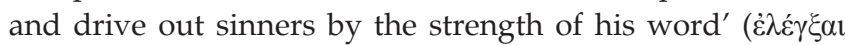

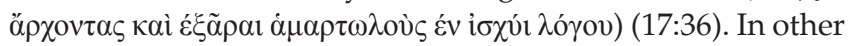
words, despite the comment in 17:32 that 'all shall be holy'

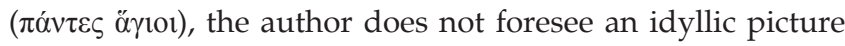
wherein everyone is suddenly inherently perfect (Embry 2002:109-110). Rather, the author foresees that holiness will be achieved through stern and uncompromising maintenance thereof by the new king. This idea is pertinently, albeit with more delicate language, expressed in 17:40: 'Faithfully and righteously shepherding the Lord's flock, he [the new king] will not let any of them stumble in their pasture.'

\section{The words 'judge' and 'judgement'}

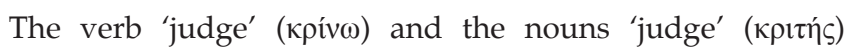
and 'judgement' ( $\kappa i^{\prime} \mu \alpha$ and $\left.\kappa \rho i ́ \sigma \varsigma\right)$ occur rather frequently throughout the Psalms of Solomon. Even a cursory survey reveals that the most important attribute of any judgement, whether by God, an earthly king or a judge, is righteousness. Two of the most common terms in the Psalms are 'righteous

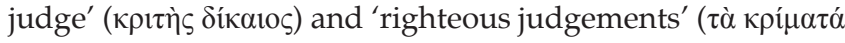

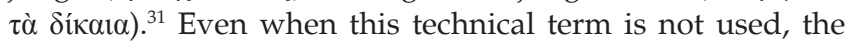

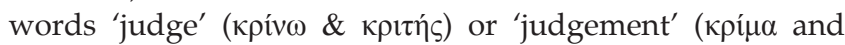
$\kappa \rho i ́ \sigma \varsigma)$ tend to occur in the same sentence together with 'prove

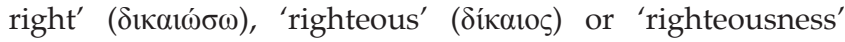

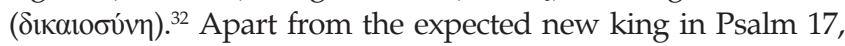
these terms and sentences unfailingly refer to the judgement

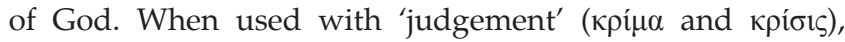

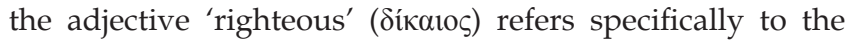
correctness, fairness, precision and impartiality of the judging

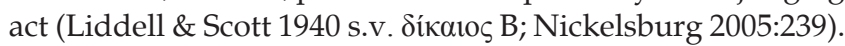
The implication is that God's judgement is well-balanced (5:4;

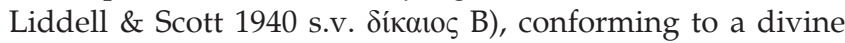
standard (Louw \& Nida 1993:744, 88.12; Newman 1993 s.v.

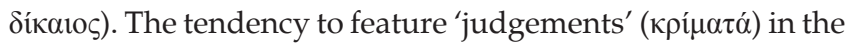
plural indicates that this noun does not refer to God's rule in general but to his individual judgements (Embry 2002:123). Yet, that God's judgement was seen as (one of) the most important and integral features of his kingly rule should not be questioned (2:30-32; 9:2, 4; Nickelsburg 2005:238). As we have seen, the judgement of God relates to the gentiles and sinners as punishment and condemnation but to the devout as mercy and salvation. God's judgement fulfils an additional function in relation to the devout, which is to chastise and discipline them..$^{33}$ The purpose hereof is both to reprimand blunders and to prevent similar mistakes in future. That is why the Psalmist can say that God's judgements upon the devout are 'kind' ( $\chi \rho \eta \sigma \tau o ́ s)$ (8:32) and necessary (Embry 2002:123). God forgives the few sins of the righteous (9:7; 16:3; Nickelsburg 2005:240-241, 244).

\section{Psalms of Solomon 17:26}

Psalm 17:26 should be read in light of everything that has thus far been discussed. The verse claims that the new king

31.Cf. $2: 10,18 ; 5: 1 ; 8: 8 ; 9: 2 ; 9: 5$.

32.Cf. $2: 15,18,32 ; 3: 3 ; 4: 8,25 ; 8: 24,25,26 ; 10: 5 ; 17: 29$.

33.Cf. $3: 4,8 ; 7: 3,9 ; 8: 26 ; 10: 1-8 ; 13: 6-12 ; 14: 1 ; 16: 1-15 ; 18: 3-4$. 
'will judge the tribes of the people, that have been made holy

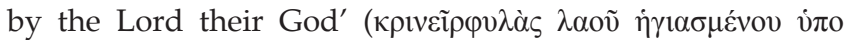

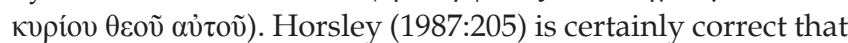
the recipients of this judgement are the remnant of Israel who are left over after God has purified Israel by condemning the gentiles and sinners (cf. Puech 2006:260). Apart from the participial phrase 'that have been made holy by the Lord

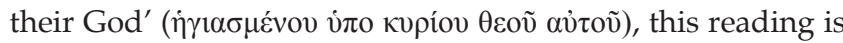
also put beyond serious doubt by the beginning of verse 26 , which describes what the new king will do directly before judging the tribes: 'He will gather together a holy people'

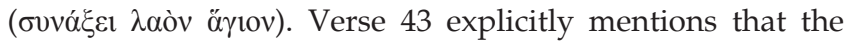
new king will judge 'the tribes of the sanctified' ( $\varphi v \lambda \dot{\alpha} \varsigma$ $\dot{\eta} \gamma\left(\alpha \sigma \mu \varepsilon v^{\prime} \omega v\right)$. Horsley correctly deduces from this that the

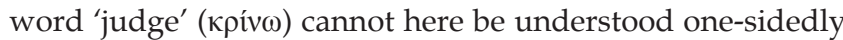
as 'condemnation'. Why would God save the righteous only to have the new king condemn them directly thereafter? Such condemnation would render nonsensical the words of verse 44: 'Blessed are those born in those days to see the good fortune of Israel, which God will bring to pass in the assembly of the tribes.' However, for Horsley to then conclude that 'judge' must here means 'liberate' is similarly one-sided. If the remnant of Israel has already been liberated by God, why would they need additional liberation directly thereafter? The literary context in Psalm 17 rather seems to suggest that the verb 'judge' should here be understood in relation to the new king's most important function in the new dispensation, which is to purify Israel and keep her holy (cf. Embry 2002:109, 121, 133). ${ }^{34}$

Like all other kings in Israel's past, the new king will represent God on earth (Nickelsburg 2005:241). The difference is that, unlike earlier kings, he will be completely pure and will not age (17:32-38). As God's representative, this new king will carry out God's work as described in the other Psalms (Embry 2002:113). Like God chastised and disciplined the devout through judgement, the new king will do the same in the new dispensation. ${ }^{35}$ Like God oversaw people on earth with his righteous judgements (9:5), the new king will now lead and judge everyone in righteousness (17:26, 40; Trafton 2006:453). Like God's most important function was that of judge (Nickelsburg 2005:238), the same is true for the new king. Psalm 17 repeatedly describes how the new king will punish and refuse to tolerate unrighteousness. ${ }^{36}$ Verse 42 expressly states that God will appoint the new king in order to discipline Israel. It seems that Horsley's

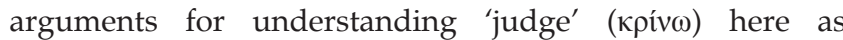
'liberate' are unsupported (and plainly contradicted) by

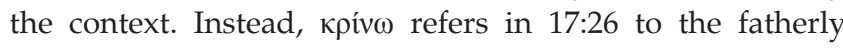
disciplining of Israel in the new dispensation, and it fulfils the purpose of protecting Israel from God's condemnation by keeping her holy (Nickelsburg 2005:243; Puech 2006:260; Wright 1985:644, 645-646).

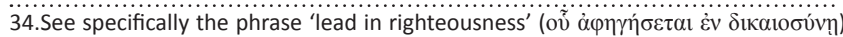
in 17:26.

35.This should not be understood in the sense that the new king replaces God but in the sense that God now performs his tasks through the new king (cf. Embry 2002:113, 115; Nickelsburg 2005:241, 242-243). God remains the acting Subject, albeit from behind the scenes (cf. De Jonge 1991a:11, 12).

36.Cf. $17: 27,29,30,32,36,40,41,42,43$.

\section{The Community Rule \\ Boundaries and judgement in the sectarian Dead Sea Scrolls}

This introductory section deals specifically with the sectarian texts found amongst the various Dead Sea Scrolls as well as the communities responsible for these writings, whom I will dub the 'Dead Sea sects'. ${ }^{37}$ There are a number of similarities between the Dead Sea sects and those responsible for the Psalms of Solomon. To a large extent, the existence of both movements ${ }^{38}$ can best be explained as a reaction against the Hasmonean priesthood. ${ }^{39}$ Both emphasised the importance of purity and the implementation of discipline amongst their members. ${ }^{40}$ According to both movements, eschatological salvation and punishment had been preordained by God whilst human action determined culpability. ${ }^{41}$ Both movements further had a clear messianic outlook and expectation (Collins 1997a:75, 1998:158). Also, both movements believed that God's eschatological intervention would be decisive and final (De Jonge 1991b:47). Most importantly for our purposes, though, both movements understood and described their respective worlds in dualistic terms. Like those behind the Psalms of Solomon, the Dead Sea sects polemically distinguished themselves from gentiles and other Jews.

As we shall presently see, the Jewish outsiders are identified by the sectarian scrolls as the leaders and citizens of greater Israel. These scrolls apply a number of derogatory epithets to these outsiders, including 'sons of darkness' (בני חושך), 'lot of Belial' (בורל בליעל), 'sons of deceit' (בני עול), 'men of injustice' (אנשי העול) and 'the wicked' (ברשים). (ברעלים. are accused of a host of sins, including (1) greed, wealth and lacking pity for the poor; (2) injustice, cruelty, stealing from the poor and oppressing the people; (3) irreverence, pride, haughtiness, impudent enthusiasm, disrespect, licentiousness and arrogance; (4) deceit, dishonesty, trickery, insincerity, (evil) cunning, treachery, withholding knowledge and fraud; (5) impatience and intolerance; (6)

37.This term deliberately features in the plural so as to include under one umbrella term all the various sectarian communities, groups and movements represented by the different sectarian writings found at Qumran. It is accepted that the various Dead Sea sects, specifically, had much in common. This section deals with those commonalities.

38.When I refer in this section to the Dead Sea sects as a 'movement', it is merely a convenient way to highlight some of the most visible commonalities between a number of different sectarian groups. The term 'movement' could incorporate either one or more than one constituent group or groups.

39.For more on this, see for example Blenkinsopp (2005:11), Collins (1998:158) Horsley (2006:47-48), Kapfer (2007:164-177), Klawans (2010:383-384), Knibb (2010:420) and Schiffman (1994:125).

40.For more information about the (moral and ritual) purity concerns amongst the Dead Sea sects, see for example Arnold (2006:28, 190-193), Collins (2010:156), Daise (2007:157-160), Embry (2002:132-133), Himmelfarb (2001:9-37), Horsley (2006:52-53), Ginsburskaya (2010:77-90), Lawrence (2005:88) and Klawans (2010:377-402, esp. 381, 382). To a great extent, both their purity concerns and their reaction against the Jerusalem temple are indicated in the archaeological remains at Khirbet Qumran (Klawans 2010:384).

41.For a more detailed discussion on predestination and free will in the Dead Sea (2006:64-66), Broshi (2006:235-246), Collins (1994:150, 380), Vande and Timmer (2009:345-347, 350-352).

42.To these could be added, amongst others: 'rebels', 'enemies', 'traitors', 'igniters of fire', 'vipers', 'council of futility', 'lot of darkness', 'sinners', 'vicious men', 'devilish assembly', 'sowers of fraud', 'hypocrites', 'viper's venom', 'lion cubs', 'serpent's venom' and 'wretched ones'. 
insanity, unintelligence, delusion, miscomprehension and a lack of enlightenment; (7) failure to keep the Laws of God, purposeful disobedience, forsaking and despising God and his Covenant, unfaithfulness, doing what is right in their own eyes, plotting and spying against God's precepts and refusing to enter God's covenant; (8) defiling the temple and violating the Sabbath and other religious festivals; (9) resenting their brothers, hating their fellow men and despising their blood relatives; (10) persecuting and stealing from their neighbours; (11) avenging themselves and plotting evil against the community; (12) impure deeds and fornication and (13) idolatry, apostasy and sleeping with foreigners. ${ }^{43}$ This list bears a striking resemblance to the sins identified by the Psalms of Solomon for their Jewish outsiders.

In this regard, there is an important difference, however, between the two movements. Whereas those behind the Psalms of Solomon still saw themselves as part of greater Israel, the Dead Sea sects did not (Davies 2008:33; Newsom 2008:16; Qimron 2006:195). In their minds, they constituted the true Israel. ${ }^{44}$ They had no sense of corporate guilt either. In no way whatsoever did they see themselves as sharing in the sins of their forefathers or their fellow countrymen (e.g. CD 2:7-10; 3:13-14). ${ }^{45}$ Instead, they saw themselves as the exclusive possessors of a correct interpretation of the Torah, which meant that no one else could truly or possibly live in accordance with God's commands (e.g. 1QS5:7-13; e.g. Brooke 2005:57-59; Hempel 2003:69-76). ${ }^{46}$ New initiates had to swear an oath that they would 'revert to the Torah of Moses' (לושה) (לשוב אל תורת (1QS 5:8). In a word, the Dead Sea sects were 'part of the true covenant - perfect and holy' (Lawrence 2005:92). ${ }^{47}$ Greater Israel in toto had been influenced by demonic spirits, which caused them to live in error (Arnold 2006:28; Collins 1997a:17, 91). It follows that the covenantal promises of old were now believed to apply exclusively to the Dead Sea sects (Nickelsburg 2008:24; Timmer 2008:396). For all intents and purposes, they viewed themselves as the replacement of greater Israel and its flawed cult (Timmer 2009:342, 344). There was no overlap of in-groups like we saw in the Psalms of Solomon. Instead, there was only the Dead Sea sects and everyone else (Harrington 2008:187-203).

43.Cf. 1QS $1: 23 ; 3: 20-21 ; 4: 8-11,19 ; 5: 12 ; 40257$ frag. $1,3: 1-7 ;$ CD $1: 1-4 ; 3: 6-21$; 4:12-19; 5:16-17; 8:5-6; 19:13-19; 20:8-12; 4Q266 1:10; 4Q267 frag. 2, 1:6-9; frag. 2, 2:1; frag. 3, 2:9-13; 4Q162 frag. 1, 2:6-8; 4Q163 frag. 26:1-3; 4Q165 frag. 6:1-6; 4Q169 frags. 3-4, 2, 8; 1QpHab 3:4-6; 8:8-13; 12:1-15; 13:1-4; 4Q171 $1: 26-27 ; 3: 7-8 ; 4: 8 ; 10221: 6-11 ; 4 Q 390$ frag. $2,1: 8-10 ; 4 Q 3862: 3-4 ; 3: 1 ; 1 \mathrm{QH}$ $10: 16$; $11: 6-18$; $21: 16$; $4 Q 430$ frag. $1: 1-7$; 1034 frag. $3,2: 3-4 ; 4 Q 400$ frag. 1 1:14-16; 4Q280:7.

44.Davies (2008:33) explains that 'there are three "Israels" in play: [1] the sect, [2] the discredited entity of the past, a nation punished by exile, and [3] a continuing, equally discredited entity, the contemporary Jewish society outside the sect'. The following authors agree that the Dead Sea sects viewed themselves as the true Israel: Blenkinsopp (2005:11), Brooke (2005:50-51), Collins (1997a:91), Davies (2008:33), Harrington (2008:203), Horsley (2006:50, 52), Lawrence (2005:87, 89, $90,99)$ and Shemesh (2002:54).

45.New initiates had to confess not only their individual sins but also their corporate sins as part of greater Israel before they could receive God's mercy and become part of the in-group (cf. 1QS 1:24-2:1).

46.Cf. 1OS 1:20-26; 5:11; CD 1:1-4; 4Q397 frags. 7-8:7-11; 11Q13 2:12; 4Q162 frag 1. 2:6-8; 4Q163 frag. 23:14; 10 pHab 2:1-10; 5:5-6, 11-12; 8:10; $4 \mathrm{Q} 171$ 2:14-15; $4 \mathrm{Q} 390$ frag. 1:7-10; $1 \mathrm{QH} 6: 5-6,24-25$.

47.Cf. 1QS 3:3-4; 11:2; CD 20:2; 1QM 1:16; 14:7; 16:1; 11Q13 2:9; 1QH 6:6; $1 \mathrm{QH}$ 19:11; 4Q511 frag. 35:3; 4Q511 3:2; 1Q34 frag. 3, 2:5-7; 4Q509 frags. 97-98, 1:5-9; 4Q405 frag. 23, 1:10-13.
This strictly sectarian mindset had an impact on their expectations of the apocalyptic future. The Dead Sea sects believed that they had been elected and earmarked by God for eschatological salvation (Collins 1997a:17; Qimron 2006:195). As it were, God's mercy, forgiveness and pity were reserved for the in-group. ${ }^{48}$ The flipside of this soteriology is that the Dead Sea sects harboured 'an exclusivism which denied salvation (with special emphasis on election, its sine qua non) to all those outside the group' (Timmer 2008:395) ${ }^{49}$ Apparently, the out-group did not deserve God's mercy, forgiveness or pity..$^{50}$ The Dead Sea sects foresaw the complete annihilation of all gentiles at the ultimate end (Schiffman 1994:371,379, 380-382). What is more, they similarly foresaw the total eradication of all Jews who were not part of the sectarian movement (Collins 1997a:108, 122, 1998:157, 171, 173; Qimron 2006:195, 197; Shemesh 2002:55-57). ${ }^{51}$ These Jewish outsiders were destined to experience everlasting and eternal torments in Sheol..$^{52}$ In other words, the post-apocalyptic world would be devoid of all other people, containing only members of the Dead Sea sects (Schiffman 1994:382). Such eschatological expectations differ extensively from those described in the Psalms of Solomon where the gentile nations subsist under the dominion of a restored Israel, and the Diaspora flock to Palestine. For the Dead Sea sects, the restoration of Israel entailed the extermination of everyone else so that only the 'true Israel' remained (Harrington 2008:203). ${ }^{53}$

\section{The Community Rule}

These themes are prevalent in the Community Rule found in the first Qumran cave (Lawrence 2005:100). In particular, the dualistic worldview of the 'community' or Yahad (יחד) is systematically developed in the pericope on the two spirits (3:13-4:26). This passage explains that, when God created the world, He neatly divided all of humanity into two opposing camps. God preordained every human being to

48.Cf i0s 11.9-15. 1105 18.16, $19: 10,13-14,24.6-7,11.1106$ frag a.5-7. fra. b. 4Q381 frag. 15:2; frag. 33:4-5; 1QH 4:11-23; 5:4-5, 20-23; 8:16-17, 24-26; 9:21-27, $31-33 ; 10: 22-23 ; 12: 37 ; 13: 4-6 ; 14: 8-9 ; 15: 28-31,34-35 ; 17: 14-15,31-34 ; 18: 15-$ 31-33; 10:22-23; 12:37; $13: 4-6 ; 14: 8-9 ; 15: 28-31,34-35 ; 17: 14-15,31-34 ; 18: 15-$ 16, $21 ; 19: 7-12,29-32 ; 1 Q 35$ frag. $1: 1-11 ; 4 Q 428$ frag. 7:1-2; $4 Q 521$ frag.
4Q504 frag. 4:6-7; $4 Q 506$ frags. 131-132:11-14; $4 Q 434$ frag $1,1: 4-7$.

49. Horsley (2006:50) admits that the Dead Sea sects understood themselves 'as constituting the renewed Israel' but qualifies this statement with the phrase 'now underway or in preparation'. Horsley (2006:52) further admits that the Dead Sea sects saw themselves as 'the only righteous ones'. However, he continues by stating that the future of greater Israel depended on the righteous remnant. Finally, Horsley (2006:59) admits that the Dead Sea sects saw themselves as both a 'reconstitution' and a 'restoration of Israel' but continues to qualify these statements with the phrase 'albeit provisional and by anticipation'. These qualifications betray Horsley's erroneous and unsubstantiated belief that the Dead Sea sects anticipated the liberation of greater Israel (including Jews who were not part of the sect) in the apralyptic future. We have seen, however, the not part of the sect) in was not the case. According to the Community Rule (and other sectarian scrolls), apocalyptic restoration applied exclusively to the Dead Sea sects (Ginsburskaya
2010:85).

50.Cf. 1QS 2:7-8; 10:20; 4Q256 4:1-2; 4Q257 frag. 1, 2:4-5; 3:1-7; 4Q260 frag. 1, 5:1; 4Q496 frag. 12, 4:1; 11Q20 frag. 20:1-7; 1QpHab 6:10-12; 7:16; 4Q201 2:15-16; 1QH 14:32; 11Q11 3:6; 4Q280:1-7.

51.Cf. 1QS 4:14; 5:12-13; 4Q257 frag. 1:3; CD 2:5-9, 20-21; 8:1-6; 19:13-19; 4Q267 frag. 2 , 2:19-21; $10 M 1: 5-10 ; 4: 2 ; 6: 3 ; 11: 1,6-7 ; 15: 1-3,9-11 ; 18: 12 ; 4 Q 496$ frag. $11,4: 1 ; 11 Q 19$ 62:13-16; 4Q161 frags. 2-4, 2:1-6; 4Q163 frags. 4-6, 2:12-18; frags. $18-19: 1-4 ; 4 Q 169$ frags. $1-2: 3-4$; frags. 3-4:2, 9-10; 1QpHab 6:10-12; 4Q171 2:7-8; 3:12-13; 4Q201 1:1; 2:12-17; 4Q542 2:8; 1Q22 1:10-11; 4Q375 1:4-5; 4Q390 frag. 2, 1:6-7; $1 \mathrm{QH}$ 12:20; 14:17-19, 29-32; 4Q280:4-5; 4Q286 frag. $7,2: 6-8$.

52.Cf. 1QS 2:8; 4:12; 4 Q256 4:1; 4Q257 frag. 1, 2:4-5; $1 \mathrm{QM}$ 15:2; 18:11; $4 \mathrm{Q} 496$ frag. 3. 1:1-7: 1 OpHab 10:3-5, 13; $402012: 15-16 ; 40204$ 6:13-15; $402124: 19-23$; 4Q542 2:5-7; 1QH 21:16; 11Q11 3:7-12; 4:5-13; 4Q418 126:7; 4Q280:4-5; 4Q286 frag. 7, 2:4-5, 9 .

53.Cf. 1QS 10:11, 13, 16; 4Q264 frag. 1:1-3; 4Q88 9:5-9; 1QH 10:23-24. 
live according to one of two unchanging spirits, namely the spirit of light and truth or the spirit of darkness and deceit $(3: 19,25)$. Those who lived in accordance with the spirit of truth were commonly described as the 'sons of light' (בני אור) and fully represented within the in-group whilst those who lived according to the spirit of deceit were called the 'sons of darkness' (בני חושך) and constituted the entire out-group (Arnold 2006:34; Harrington 2008:191; Nickelsburg 2008:24). Joining the Yahad entailed loving the sons of light and hating the sons of darkness (1:9-11). Expulsion from the Yahad meant that the culprit was no longer regarded as part of the sons of light but rather now belonged to the sons of darkness (Arnold 2006:78; Shemesh 2002:46-52).

According to the Community Rule, the sons of light originally sprang from a fountain of light. They were governed by the 'prince of lights' (שר אורים) and supported by the God of Israel and his 'angel of truth' (מלאך אמתו). Their attributes included humility, goodness and wisdom. Their apocalyptic fate would entail 'plentiful peace in a long life, fruitful offspring with all everlasting blessings, eternal enjoyment with endless life, and a crown of glory with majestic raiment in eternal light' (4:7-8). Conversely, the sons of darkness originated from a source of darkness. They were governed by the 'angel of darkness' (מלאך חושך), who caused all their unlawful deeds. Their personal characteristics included wickedness, falsehood and greed. Their apocalyptic fate would entail:

... a glut of punishments at the hands of the angels of destruction, for eternal damnation for the scorching wrath of the God of revenge, for permanent error and shame without end with the humiliation of destruction by the fire of the dark regions. (1QS $4: 12-13)$

The text continues to explain that these sons of darkness would ultimately be completely destroyed 'without there being a remnant or a survivor among them' (4:14). The purpose hereof was to obliterate the existence of injustice in the world forever (e.g. 4:18-20). The purpose of God's apocalyptic judgement was to establish a world where there would be no more injustice, deceit or evil of any kind.

However, the Community Rule distinguishes a period of more stringent purification and refinement before God would finally arrive to judge the world. At the time of writing, this period had not yet commenced, meaning that it was still part of the Yahad's expected eschatological future (Collins 1997b:80-81, 2010:168). In other words, the Yahad expected a period in the future, but before 'the time appointed for judgment', when 'God will refine, with his truth, all man's deeds, and will purify for himself the configuration of man' (4:20). This refinement applied only to the sons of light (Flint 1997:60). Although they were not governed by the spirit of deceit like the sons of darkness, they were nonetheless impacted by it. Accordingly, 'the spirits of truth and of injustice feud in the heart of man' (4:23), including the hearts of the sons of light (Collins 1998:153; Levison 2006:177-185; Knibb 2010:408). ${ }^{54}$ On occasion, the angel of darkness also

54. Broshi (2006:238-239) explains that the Dead Sea sects upheld a system in which every human being is composed of nine parts - some of light and some of darkness (4Q186 [Horoscopes or 4QCryp ${ }^{a}$ ]). By this system, in which the number of parts is uneven, everyone belongs to one of the two camps' (cf. also Knibb 2010:408). caused the sons of light to stray $(3: 21-24 ; 11: 9-10)$. As we saw, however, members of the in-group had exclusive access to God's forgiveness. Although the standard seems to have been nothing less than perfection (e.g. 2:8-9; Arnold 2006:41-43, 58, 78-80), the Yahad was well aware that they still lacked complete and utter perfection (Puech 2006:271, 272; Shemesh 2002:56). Nevertheless, it foresaw a time before the ultimate end when God would completely purify every son of light, 'ripping out all spirit of injustice from the innermost part of his flesh, and cleansing him with the spirit of holiness from every irreverent deed' (4:20-21). As a result of such purification, this epoch would be characterised by 'perfect behaviour' and the absence of injustice amongst the sons of light (4:22-23; Flint 1997:60). Such decontamination and perfection occurs in preparation of the final judgement, enabling God (who abhors injustice) to liberate the sons of light whilst condemning the sons of darkness (4:22-26).

This period of preparation should in all probability be identified with the eschatological phase otherwise known in the sectarian writings as the 'end of days' (אחרית הימים). The 'end of days' included not only the testing and refinement of the in-group but also the restoration of the legitimate temple cult through the establishment of a new temple (e.g. Collins 1997a:56-58, 1997b:79-82, 1998:157)..$^{55}$ It seems likely that the new temple expected by some of the Dead Sea sects at the end of days was not a physical building but the sects themselves, who represented the temple through their perfect behaviour and ritual purity (Collins 1997a:58, 60; Horsley 2006:47-48). ${ }^{56}$ Regardless of whether the temple of the 'end of days' was an actual building or the sects themselves, the final, eschatological temple building would only be constructed after the final judgement (Collins 1997a:58, 60, 108). The 'end of days' also involved the appearance on the scene of no less than two messiahs. ${ }^{57}$ The new Davidic king would do his part in restoring the kingdom of Israel and establishing the new temple cult by conquering the gentiles and subduing the sons of darkness (Collins 1997a:80-85, 90, 1997b:86, 1998:157-160). After such military conquest, this new king would rule over all the subjugated people, which would include fulfilling the traditional kingly role of judge (VanderKam \& Flint 2002:266-267). Additionally, the priestly messiah would do his part in establishing and maintaining the new temple by atoning for the sin of Israel, upholding the ritual and moral purity of the Dead Sea sects and acting as teacher and judge (Arnold 2006:194-197). All of this is still only part of the 'end of days', which should not be confused with the ultimate end. The construction of the ultimate post-apocalyptic temple building as well as the extermination of all gentiles and Jewish outsiders must await the final judgement of God at the apocalyptic end (Puech 2006:279).

55.Timmer (2009:342) refers to Collins (1997a:52-70) when he claims that the time of testing' should be separated from the 'end of days'. In this regard, Timmer seems to have misread Collins, who clearly describes the testing and refinement of the in-group as one of the integral 'aspects' of the 'end of days'.

56. Before the arrival of the 'end of days', the Dead Sea sects already saw themselves as a replacement of the temple in Jerusalem (see Kapfer 2007:164-165, 169-172). If the 'end of days' temple was also the sect itself, instead of an actual building, the difference between the two temples might very well have entailed nothing more than an upgrade in the degree of its holiness and perfection.

57.For more information on these two Messiahs, see Collins (1997a:77-87, 1998:160-166), Hughes (1997:12), Neufeld (1997:121), VanderKam and Flin (2002:265), Werman (2009:294-295) and Knibb (2010:420-425). 


\section{The words 'judge' and 'judgement'}

The theme of judgement is prevalent in the sectarian Dead Sea Scrolls (Knibb 2010:413). Throughout these texts, the eschatological condemnation of outsiders is viewed as a positive happening since it constitutes the liberation of the ingroup. This explains why the Dead Sea sects have no qualms about referring to the condemnation of outsiders as evidence of God's 'merciful judgement' ${ }^{58}$ In fact, the destruction of outsiders is for them a source of delight. ${ }^{59}$ In the Community Rule, the words 'judge' (שפט) and 'judgement' (משפט) function in the following ways: (1) as something that each member of the Yahad must practice internally, semantically similar to the English words 'justice' (as opposed to injustice) and 'discernment' (in the sapiential sense) $(1: 5 ; 3: 1 ; 5: 4 ; 6: 23 ; 8: 9$; $9: 5 ; 10: 25 ; 11: 2,5),(2)$ to denote judicial judgement executed either within the Yahad before the 'end of days' or by the Yahad during the 'end of days' (5:3, 6; 6:9, 22, 24; 8:2, 3, 25; $9: 7,15,17),(3)$ as part of a temporal phrase to refer to the time when the final judgement will take place (4:20), (4) to describe God's this-worldly reproach and disciplining of the in-group $(10: 11,13,16,18,23 ; 11: 10,12,14)$ and (5) to describe God's comprehensive condemnation of outsiders at the final judgement $(1: 26 ; 5: 12-13 ; 8: 6-7,10 ; 10: 20)$. Like in the Psalms of Solomon, the word 'judgement' commonly occurs together in the same sentence with variants of the word 'righteousness' (צדק) (1:5, 26; 3:1; 5:4; 8:2; 9:17; 10:11, 25; 11:5).

\section{QS 8:1-4}

Everything discussed up to this point in the current section is relevant to our interpretation of 1 QS $8: 1-16$. Like the discourse on the two spirits (3:13-4:26), this text deals with the interim period of refinement and purification. That the events described here had not yet occurred is indicated by its use of future verbs (8:5-16; Berg 2007:167-168, esp. n. $20,21,23,26)$ and future-oriented temporal phrases (8:4, 12; 9:3; Collins 2010:161). Furthermore, that these events precede the ultimate end is indicated by the description of eschatological events that have not yet been fulfilled like the 'atonement of the earth' (לכפר בעד הארצ) and the 'rendering of retribution to the wicked' (ולהשב לרשעים גמולם) (8:6-7, 10). The wicked are still part of this messianic world and will only be condemned at the final judgement (Hempel 2008:56). Like the Dead Sea Scrolls that deal with the 'end of days', 1QS 8:5-15 describes the Yahad of the messianic age as a type of substitute temple (Collins 1997a:60, 148; Horsley 2006:47). However, it is clear from the phrase 'when these things [or men] ${ }^{60}$ exist in Israel' (בהיות אלה בישראל) in 1QS 8:4 that there was a precondition for the commencement of this messianic epoch. This precondition is described in 1QS 8:1-4, which begins by prophesying that 'in the Yahad Council [there shall be] twelve men (שנים עשר איש) and three priests (וכוהנים שלושה)'. Although there is some disagreement amongst scholars

58.Cf. 4Q491, frags. 8-10, 1:6; $4 Q 200$ frag. $7: 5-7 ; 1 Q H$ 14:9; $4 Q 427$ frag. $7,1: 21-22$; 2:15; 4Q434 frag. 1, 1:7

59.Cf. $1 \mathrm{QM} 13: 16 ; 4 Q 496$ frag. 3, 1:9; $4 Q 163$ frags. 18-19:1-4; $4 Q 381$ frag. 33:5-6; 1QH 19:22-23; 4Q427 frag. 1:4-6.

60.Berg (2007:166-167, esp. n. 18) notes the possibility that the demonstrative pronoun הלא refers here to the 15 men in the foregoing verses (cf. also the translation of Wise, Abegg \& Cook 2004:31). about the correct interpretation of the term 'Yahad Council' or 'Council of the Yahad' (עצת היחד), it seems most likely that this term functioned as an alternative self-designation of the Yahad proper (יחד) (Berg 2007:165-166; Collins 2010:161; Hempel 2003:75, 2008:44, 49-54; Metso 2008:72-77, 80-81). ${ }^{61}$

Regarding the twelve men and three priests, Berg (2007:161-177) has argued persuasively (and conclusively, in my opinion) that they constituted an 'elite group' within the (council of the) Yahad and should not be interpreted to be only a symbolic description of the Yahad proper (cf. Collins 1998:176, 2010:161-162; contra Metso 2008:78-84). ${ }^{62}$ There should be no doubt that the numbers 'twelve' and 'three' refer to the twelve tribes of Israel and the three tribes from Levi respectively (Hempel 2008:54; Metso 2008:81; Collins 2010:162). More specifically, if 1QS 8:1 is read in combination with 4Q164, where the number 'twelve' ([...] שנים עשר) is combined with a reference to 'the heads of the tribes of Israel' (ראשי שבטי ישראל), it remains difficult to see the twelve men (and three priests) as anything other than leaders of the different tribes (contra Metso 2008:81). Unlike the rest of the Yahad, this 'elite group' of tribal leaders is often described as being not merely 'perfect' (תםים) or 'holy' (תודש) but as walking in 'perfect holiness' (תםים קודש) (8:20, 21; 9:6, 8; Berg 2007:171-172). ${ }^{63}$ The Damascus Document also seems to describe leaders of (some of) the Dead Sea sects as men of 'perfect holiness' (Kapfer 2007:154). This term (תםים קודש) denotes a greater degree of holiness and perfection than either word (קודש תמודש (תםים) on its own (Collins 2010:163). It implies being completely and utterly untarnished. Such 'perfect holiness' would one day be established and maintained through trials, which the tribal leaders would undergo voluntarily (8:4; cf. 9:10). The text does not specify who would be the judge or judges at these trials, but if the phrase 'undergoing trials' (מצרפ צרת) is read in conjunction with both 1QS 9:7-8, 12-21 and the Liturgy of the Tongues of Fire (4Q375; 4Q376; 1Q29), the most likely candidates seem to be either the priestly messiah or the Maskil (Arnold 2006:194-197, 201; Berg 2007:173-176). In other words, before and during their leadership, the 15 would themselves be subjected to a process of judgement and purification.

Once determined to be 'perfectly holy', the 15 tribal leaders would be ready to 'implement truth, justice [and] judgment' (לעשות אמת וצדקה ומשפט) and to 'do justice' (בעושי משפט). These phrases probably refer to the role of the 15 as judges of their respective tribes. To a certain extent, independent evidence hereof is provided by the War Scroll (4Q491 frags. 1-3:9-10) where priests, Levites and the 'chiefs of the camps' (תרי) המחנות) are responsible for judging the men of the tribes before they go into battle (cf. Arnold 2006:199). Better support

61.Cf. $3: 2 ; 5: 7 ; 6: 3,10,12-13,14,16 ; 7: 2,22,24 ; 8: 5,22 ; 11: 8$. In my view, this term particularly described the Yahad when it was assembled for a meeting of some kind, whether or not they were joined by others (cf. 1QSa 1:25-27; 2:1-3; cf. Arnold 2006:36; Hempel 2008:46).

62.It should be pointed out that both interpretations would support my current case against Horsley. In fact, it would have been more conducive to my overall argument if the 15 were symbolic of the whole Yahad. I do not believe this to be the case, however.

63.Arnold (2006:41-43) applies the term 'perfect holiness' to the whole Yahad not just the 'elite group' of 15. Such a reading fails to acknowledge that, in the rest of the Community Rule, this term occurs only in reference to the elite group. 
comes from the Damascus Document (CD 10:4-10) where the representative leaders of the tribes of Israel and Levi are expressly described as 'the judges of the congregation' (cf. Metso 2008:67). ${ }^{64}$ The purpose of such judgement would be to 'implement compassionate love and unassuming behaviour' and to 'preserve faithfulness on the earth with firm purpose and repentant spirit in order to atone for sin'. In other words, the purification of the Yahad would occur through judgement of its members by the newly appointed tribal leaders. Like the Psalms of Solomon, the Community Rule foresees a messianic age during which a remnant of Israel will be purified and kept holy through judgement of the in-group. According to the Community Rule, God will use tribal leaders to weed out imperfection in preparation for the final judgement. The result of all this will be a perfect community or Yahad (8:4), who will not only represent the temple through perfect behaviour (8:4-11) but will also be totally ready for final judgement (Kapfer 2007:169-170). The period of purification and perfection is followed by the ultimate end during which the whole Yahad will 'atone for the earth' (לכפר בעד הארצ) and 'render the wicked their retribution' (ולהשב לרשעים גמולם), thereby eradicating evil forever $(8: 6-7,10)$. Ultimately, it is the Yahad as a whole who will judge greater Israel (Berg 2007:167). Such judgement will entail 'vindication of the just and judgement of the wicked' (Berg 2007:168).

\section{Conclusion}

We need to draw a distinction between Horsley's broader argument, that Q 22:28, 30 deals with the restoration of Israel, and his narrower argument, that the verb 'judge'

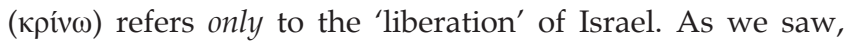
Horsley uses the narrower claim as support for his broader claim. Regarding the latter, Horsley is probably correct that Q 22:28, 30 has the restoration of Israel in view. This is indicated above all else by the deliberate mentioning in

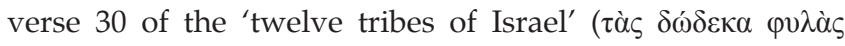

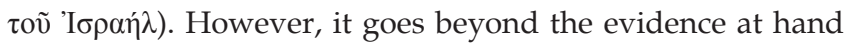
to suggest, on the one hand, that the verb крív $\omega$ must here be understood to mean 'liberation' and, on the other hand, that Q 22:28, 30 therefore promotes an exclusively positive understanding of Israel's restoration. Amongst other equally fragile arguments (see Howes 2014), Horsley bases both of the latter claims on the two intertexts that received attention here. As we saw, the Psalms of Solomon do not qualify as

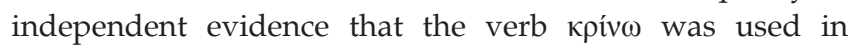
Second-Temple Judaism to express the wholesale liberation of greater Israel. It was rather proposed that кpiv $\omega$ was used in Psalm 17:26 to express judicial judgement by the messianic king in the new dispensation, the purpose of which would be to purify Israel and keep her holy. Yet, even if this suggestion is denied, it would still be a far cry to propose that кpiv means 'liberation' in Psalm 17:26. Nowhere else in the document is this verb used in such a way. Neither does the Community Rule qualify as independent evidence that the words 'judge' (שפט) or 'judgement' (משפט) were used in plus six from Israel add up to ten (cf. Metso 2008:67). the way proposed by Horsley. Rather, 1QS 8:1-4 describes a messianic future when 15 individuals would judge the Yahad in order to decontaminate it and keep it holy. In the larger scheme of things, the purpose hereof would be to weed out imperfection in preparation for the final judgement. Even if my interpretation of $Q$ 8:1-4 and its understanding of 'judgement' misses the mark, it is still a long shot to argue that 'judgement' here means 'liberation'. This preparatory process of judgement might ultimately lead to salvation at the apocalyptic end, but the word 'judgement' (משפט) certainly does not semantically mean 'liberation' in and of itself.

There are also noteworthy disparities between the Q logion and the two intertexts. As Horsley (1999:262) agrees, it is highly unlikely that $Q$ 22:28, 30 had the twelve disciples in mind.$^{65}$ Instead, it held that all the followers of Jesus (oi

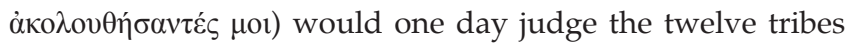
of Israel. In Psalms of Solomon 17, by contrast, it is a single individual, the new messianic king, who is expected to judge greater Israel. These two texts also disagree about the object of future judgement. Whereas Q 22:28, 30 foresees greater Israel in toto being judged, Psalm 17 only expects a remnant of Israel to fall under the rule and judgement of the new king. As far as 1QS 8:1-4 is concerned, the subject of messianic judgement would be 15 tribal leaders whilst the object would be the 'true Israel', meaning the Yahad itself. In short, whereas $Q$ 22:28, 30 envisions the entire in-group judging greater Israel in toto, the other two texts envision one or more internal leaders judging a remnant of Israel.

The latter becomes explicable if one notices the existence of a second disparity between the $\mathrm{Q}$ logion and the two intertexts. Whereas the latter texts discuss the expected messianic period, Q 22:28, 30 is about the final apocalyptic end. ${ }^{66}$ In this way, Q 22:28, 30 has more in common with other texts in the Psalms of Solomon and the Community Rule than the texts proposed by Horsley. If Q 22:28, 30 is compared to these documents and their understanding of the final judgement, it follows that this logion must have understood the final judgement to have included at least condemnation. One possibility that seems entirely excluded in view of the latter comparison is that $Q 22: 28,30$ could have understood the final judgement to entail only liberation. Like 1QS $(8: 6-7,10)$, $Q(22: 28,30)$ foresaw the entire in-group judging greater Israel at the ultimate end. Unlike the Community Rule, however, Q 22:28, 30 did not foresee the absolute destruction of the entire out-group. Like the Psalms of Solomon, the Sayings Gospel expected not only the punishment of some and the liberation of others within greater Israel but also the ingathering of the Diaspora and/or the nations (Q 13:28-29). Like both documents, Q 22:28, 30 expected the restoration and reinstatement of the twelve tribes of Israel but could not

65.For a more detailed discussion, see Lührmann (1969:97), Jacobson (1992:247), Kloppenborg (1996:327, n. 88), Davies and Allison (1997:55) and Fleddermann (2005:868-869).

66.This is put beyond serious doubt by the syntagmatic and paradigmatic contexts of $Q 22: 28,30$ in the Sayings Gospel $Q$ (see Howes 2014). It is nevertheless also possible that the 'judgement' of Q 22:28, 30 also entails judicial-type judgement (in the sense of deciding disputes) in the post-apocalyptic world (cf. 1 Cor 6:1-3). (in the sense of deciding disputes) in the post-apocalyptic world (cf. 1 Cor $6: 1-3$ ).
Even so, this judgement should still be separated from the judicial-type judgement of the messianic era. 
foresee this happening without a process of purification, after which only a remnant of Israel would be left over.

\section{Acknowledgements Competing interests}

The author declares that he has no financial or personal relationship(s) that may have inappropriately influenced him in writing this article.

\section{References}

Abegg, M., 2004, 'Serekh le'anshey ha-Yahad', in W.P. Donald \& E. Tov (eds.), The Dead Sea Scrolls reader (Part 1): Texts concerned with religious law, pp. 20-42, Brill, Leiden \& Boston, MA.

Allison, D.C., 1998, Jesus of Nazareth: Millenarian prophet, Fortress, Minneapolis, MN. Arnold, R.C.D., 2006, The social role of liturgy in the religion of the Qumran community, Brill, Leiden \& Boston, MA. (Studies on the Texts of the Desert of Judah, LX).

Atkinson, K., 1998, 'Towards a redating of the psalms of solomon: Implications for understanding the sitz im leben of an unknown Jewish sect', Journal for the Study of the Pseudepigrapha 9(17), 95-112. http://dx.doi org/10.1177/095182079800001706

Berg, S.A., 2007, 'An elite group within the Yahad: Revisiting 1QS 8-9', in T.D. Michael \& B.A. Strawn (eds.), Qumran studies: New approaches, new questions, pp. 161-177, William B. Eerdmans, Grand Rapids, MI \& Cambridge.

Blenkinsopp, J., 2005, 'The Qumran sect in the context of second temple sectarianism', in L.L. Grabbe \& J.H. Charlesworth (eds.), New directions in Qumran studies: Proceedings of the Bristol Colloquium on the Dead Sea Scrolls, 8-10 September 2003, pp. 10-25, T\&T Clark, London \& New York. (Library of Second Temple Studies 52).

Brooke, G.J., 2005, The Dead Sea Scrolls and the New Testament, Fortress, Minneapolis, MN.

Broshi, M., 2006, 'Predestination in the Bible and the Dead Sea Scrolls', in J.H. Charlesworth (ed.), The Bible and the Dead Sea Scrolls, vol, 2: The Dead Sea Scrolls and the Qumran community, pp. 235-246, Baylor University Press, Waco, TX. (The Second Princeton Symposium on Judaism and Christian Origins).

Collins, J.J., 1997a, Apocalypticism in the Dead Sea Scrolls, Routledge, London \& New York.

Collins, J.J., 1997b, 'The expectation of the end in the Dead Sea Scrolls', in C.A. Evans \& P.W. Flint (eds.), Eschatology, messianism, and the Dead Sea Scrolls, pp. 74-90, William B. Eerdmans, Grand Rapids, MI \& Cambridge. (Studies in the Dead Sea Scrolls and Related Literature).

Collins, J.J., 1998, The apocalyptic imagination: An introduction to Jewish apocalyptic literature, 2nd edn., William B. Eerdmans, Grand Rapids, MI \& Cambridge.

Collins, J.J., 2010, 'Sectarian communities in the Dead Sea Scrolls', in T.H. Lim \& J.J. Collins (eds.), The Oxford handbook of the Dead Sea Scrolls, pp. 151-172, Oxford University Press, Oxford. http://dx.doi.org/10.1163/ej.9789004185845.i-274.6

Daise, M.A., 2007, 'The covenant renewal rite and the initiation process in 1QS', in M.T. Davis \& B.A. Strawn (eds.), Qumran studies: New approaches, new questions, pp. 150-160, William B. Eerdmans, Grand Rapids, MI \& Cambridge.

Davies, P.R., 2008, “'Old" and "New" Israel in the Bible and the Qumran Scrolls: Identity and difference', in F. García Martínez \& M. Popović (eds.), Defining identities: We, you, and the other in the Dead Sea Scrolls, proceedings of the Fifth Meeting of the IOQS in Groningen, pp. 33-42, Brill, Leiden \& Boston, MA. (Studies on the Texts of the Desert of Judah, 70).

Davies, W.D. \& Allison, D.C., 1997, A critical and exegetical commentary on the gospe according to Saint Matthew, vol. 3, T\&T Clark, London \& New York. (Internationa Critical Commentary).

De Jonge, M., 1991a, 'The expectation of the future in the Psalms of Solomon', in M. de Jonge (ed.), Jewish Eschatology, Early Christian Christology and the Testaments of the Twelve Patriarchs: Collected Essays of Marinus de Jonge, Brill, Leiden, New York, Københaven \& Köln. (Novum Testamentum Supplements, LXIII).

De Jonge, M., 1991b, 'The role of intermediaries in God's final intervention in the future according to the Qumran Scrolls', in Jewish Eschatology, Early Christian Christology and the Testaments of the Twelve Patriarchs: Collected Essays of Marinus de Jonge, Brill, Leiden, New York, Københaven \& Köl. (Novum Testamentum Supplements, LXIII).

Embry, B., 2002, 'The psalms of solomon and the new testament: Intertextuality and the need for a re-evaluation', Journal for the Study of the Pseudepigrapha 13(2), 99-136. http://dx.doi.org/10.1177/095182070201300201

Fleddermann, H.T., 2005, Q: A reconstruction and commentary, Peeters, Leuven, Paris \& Dudley, MA. (Biblical Tools and Studies, vol. 1).

Flint, P.W., 1997, 'The Daniel tradition at Qumran', in C.A. Evans \& P.W. Flint (eds.), Eschatology, messianism, and the Dead Sea Scrolls, pp. 41-60, William B. Eerdmans, Grand Rapids, MI \& Cambridge. (Studies in the Dead Sea Scrolls and Related Literature).

García Martínez, F., 1994, The Dead Sea Scrolls translated: The Qumran texts in english, transl. W.G.E Watson, Brill, Leiden.

Ginsburskaya, M., 2010, 'The right of counsel and the idea of purity in the rule of the community (1QS) and the rule of the congregation (1QSa)', in D.K. Falk, S. Metso, D.W. Parry \& E.J.C. Tigchelaar (eds.), Qumran cave 1 revisited: Texts from cave 1 sixty years after their discovery, proceedings of the Sixth Meeting of the IOQS in Ljubljana, pp. 77-90, Brill, Leiden \& Boston, MA. (Studies on the Texts of the Desert of Judah, 91).
Harrington, H.K., 2008, 'Keeping outsiders out: Impurity at Qumran', in F. García Martínez \& M. Popović (eds.), Defining identities: We, you, and the other in the Dead Sea Scrolls, proceedings of the Fifth Meeting of the IOQS in Groningen, pp. 187-203, Brill, Leiden \& Boston, MA. (Studies on the Texts of the Desert of pp. 187-203,
Judah, 70).

Hempel, C., 2003, 'Interpretive authority in the community rule tradition', Dead Sea Discoveries 10(1), 59-80. http://dx.doi.org/10.1163/15685170360584155

Hempel, C., 2008, 'Emerging communal life in the S tradition', in F. García Martínez \& M. Popović (eds.), Defining identities: We, you, and the other in the Dead Sea Scrolls, proceedings of the Fifth Meeting of the IOOS in Groningen, pp. 43-61, Scrolls, proceedings of the Fifth Meeting of the IOQS in Groningen, pp. 43-61,
Brill, Leiden \& Boston, MA. (Studies on the Texts of the Desert of Judah, 70).

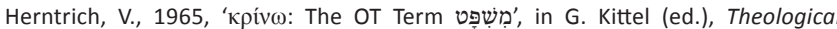
Dictionary of the New Testament, vol. III, pp. 923-933, William B. Eerdmans, Dictionary of the
Grand Rapids, MI.

Himmelfarb, M., 2001, 'Impurity and sin in 4QD, 1OS, and 4Q512', Dead Sea Discoveries 8(1), 9-37. http://dx.doi.org/10.1163/15685170151094917

Horsley, R.A., 1987, Jesus and the spiral of violence: Popular Jewish resistance in Roman Palestine, Harper \& Row, San Francisco, CA.

Horsley, R.A., 1989, Sociology and the Jesus Movement, Crossroad, New York.

Horsley, R.A., 1992, 'Q and Jesus: Assumptions, approaches, and analyses', in J.S. Kloppenborg \& L.E. Vaage (eds.), Early Christianity, Q and Jesus, pp. 175-209, Scholars, Atlanta, GA. (Semeia 55).

Horsley, R.A., 1995, 'Social conflict in the synoptic sayings source Q', in J.S Kloppenborg (ed.), Conflict and invention: Literary, rhetorical and social studies on the sayings gospel Q, pp. 37-52, Trinity, Valley Forge, PA.

Horsley, R.A. (ed.), 1999, Whoever hears you hears me: Prophets, performance, and tradition in $Q$, Trinity, Harrisburg.

Horsley, R.A., 2003, Jesus and empire: The Kingdom of God and the new world disorder, Fortress, Minneapolis, MN.

Horsley, R.A., 2006, 'The Dead Sea Scrolls and the historical Jesus', in J.H. Charlesworth (ed.), The Bible and the Dead Sea Scrolls, vol. 3: The Scrolls and Christian origins, Baylor University Press, Waco, TX. (The Second Princeton Symposium on Judaism and Christian Origins).

Horsley, R.A., 2011, Jesus and the powers: Conflict, covenant, and the hope of the poor, Fortress, Minneapolis, MN.

Howes, L., 2014, 'Condemning or liberating the twelve tribes of Israel?: Judging the meaning of кpivovtes in Q 22:28, 30', Verbum et Ecclesia 35(1).

Hughes, P.E., 1997, 'Moses' birth story: A Biblical matrix for prophetic messianism', in C.A. Evans \& P.W. Flint (eds.), Eschatology, messianism, and the Dead Sea Scrolls, pp. 10-22, William B. Eerdmans, Grand Rapids, MI \& Cambridge. (Studies in the Dead Sea Scrolls and Related Literature).

Jacobson, A.D., 1992, The first gospel: An introduction to Q, Polebridge, Sonoma, CA.

Kapfer, H.E., 2007, 'The relationship between the Damascus document and the community rule: Attitudes toward the temple as a test case', Dead Sea Discoveries 14(2), 152-177. http://dx.doi.org/10.1163/156851707781498337

Kaylor, R.D., 1994, Jesus the prophet: His vision of the kingdom on earth, Westminster \& John Knox, Louisville, KY

Klawans, J., 2010, 'Purity in the Dead Sea Scrolls', in T.H. Lim \& J.J. Collins (eds.) The Oxford handbook of the Dead Sea Scrolls, pp. 377-402, Oxford University Press, Oxford.

Kloppenborg, J.S., 1996, 'The sayings gospel Q and the quest of the Historical Jesus', Harvard Theological Review 89(4), 307-344.

Knibb, M.A., 2010, 'Apocalypticism and messianism', in T.H. Lim \& J.J. Collins (eds.) The Oxford handbook of the Dead Sea Scrolls, pp. 403-432, Oxford University Press, Oxford.

Lawrence, L.J., 2005 “"Men of perfect holiness" (10S 7:20): Social-scientific thoughts on group identity, asceticism and ethical development in the rule of the community', in L G asceticism and ethical development in the rule of the community', in L.L. Grabbe \& Qum studies, proceedings of the Bristol Colloquium on the Dead Sea Scrolls, Qumran studies, proceedings of the Bristol Colloquium on the Dead Sea Scrolls,
8-10 September 2003, pp. 83-100, T\&T Clark, London \& New York. (Library of $8-10$ September 2003, pp.
Second Temple Studies 52).

Levison, J.R., 2006, 'The two spirits in Qumran theology', in J.H. Charlesworth (ed.), The Bible and the Dead Sea Scrolls, vol. 2: The Dead Sea Scrolls and the Qumran community, pp. 169-194, Baylor University Press, . Waco, TX. (The Second Princeton Symposium on Judaism and Christian Origins).

Liddell, H.G. \& Scott, R., 1940, A Greek-English lexicon, 9th edn., Clarendon, Oxford.

Louw, J.P. \& Nida, E.A. (eds.), 1993, Greek-English lexicon of the New Testament based on semantic domains, vol. 1, (domains), United Bible Society, Cape Town.

Lührmann, D., 1969, Die Redaktion der Logienquelle, Neukirchener Verlag, Neukirchen-Vluyn. (Wissenschaftliche Monographien zum Alten und Neuen Testament, 33).

Metso, S., 2008, 'Whom does the term yahad identify?", in F. García Martínez \& M. Popović (eds.), Defining identities: We, you, and the other in the Dead Sea

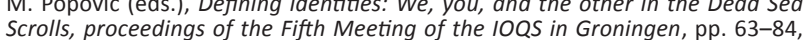
Scrolls, proceedings of the Fifth Meeting of the IOQS in Groningen, pp. 63-84,
Brill, Leiden \& Boston, MA. (Studies on the Texts of the Desert of Judah, 70).

Neufeld, D., 1997, '“And when that one comes": Aspects of Johannine messianism', in C.A. Evans \& P.W. Flint (eds.), Eschatology, messianism, and the Dead Sea Scrolls, pp. 120-140, William B. Eerdmans, Grand Rapids, MI \& Cambridge. (Studies in the Dead Sea Scrolls and Related Literature). 
Newman, B.M., 1993, Concise Greek-English dictionary of the New Testament, Deutsche Bibelgesellschaft, Stuttgart.

Newsom, C.A., 2008, 'Constructing "we, you, and the others" through non-polemical discourse', in F. García Martínez \& M. Popović (eds.), Defining identities: We, you, and the other in the Dead Sea Scrolls, proceedings of the Fifth Meeting of the IOOS in Groningen, pp. 13-21, Brill, Leiden \& Boston, MA. (Studies on the Texts of the Desert of Judah, 70)

Nickelsburg, G.W.E., 2005, Jewish literature between the Bible and the Mishnah: A historical and literary introduction, 2nd edn., Fortress, Minneapolis, MN.

Nickelsburg, G.W.E., 2008, 'Polarized self-identification in the Qumran texts', in F. García Martínez \& M. Popović (eds.), Defining identities: We, you, and the other in the Dead Sea Scrolls, proceedings of the Fifth Meeting of the IOQS in Groningen, pp. 23-31, Brill, Leiden \& Boston, MA. (Studies on the Texts of the Desert of Judah, 70).

Puech, É., 2006, 'Resurrection: The Bible and Qumran', in J.H. Charlesworth (ed.) The Bible and the Dead Sea Scrolls, vol. 2: The Dead Sea Scrolls and the Qumran The Bible and the Dead Sea Scrolls, vol. 2: The Dead Sea Scrolls and the Qumran
community, pp. 247-281, Baylor University Press, Waco, TX. (The Second community, pp. 247-281, Baylor University Press,
Princeton Symposium on Judaism and Christian Origins)

Qimron, E., 2006, 'Dualism in the Essene communities', in J.H. Charlesworth (ed.), The Bible and the Dead Sea Scrolls, vol. 2: The Dead Sea Scrolls and the Qumran community, pp. 195-202, Baylor University Press, Waco, TX. (The Second Princeton Symposium on Judaism and Christian Origins)

Robinson, J.M., Hoffmann, P. \& Kloppenborg, J.S. (eds.), 2000, The critical edition of Q, Fortress, Minneapolis, MN. (Hermeneia Series).

Schiffman, L.H., 1994, Reclaiming the Dead Sea Scrolls: The history of Judaism, the background of Christianity, the lost library of Qumran, The Jewish Publication Society, Philadelphia, PA \& Jerusalem.

Shemesh, A., 2002, 'Expulsion and exclusion in the community rule and the Damascus document', Dead Sea Discoveries 9(1), 44-74. http://dx.doi. org/10.1163/156851702320115733

Timmer, D.C., 2008, 'Sectarianism and soteriology: The priestly blessing (Numbers $6,24-26$ ) in the Qumranite community rule (1QS)', Biblica 89(3), 389-396.
Timmer, D.C., 2009, 'Variegated nomism indeed: Multiphase eschatology and soteriology in the Qumranite community rule (1OS) and the new perspective on Paul', Journal of the Evangelical Theological Society 52(2), pp. 341-356.

Trafton, J.L., 1986, 'The Psalms of Solomon: New light from the Syriac version?', Journal of Biblical Literature 105(2), 227-237. http://dx.doi. org/10.2307/3260391

Trafton, J.L., 2006, 'The Bible, the Psalms of Solomon, and Qumran', in J.H. Charlesworth (ed.), The Bible and the Dead Sea Scrolls, vol. 2: The Dead Sed Scrolls and the Qumi Scrolls and the Qumran community, pp. 427-446, Baylor University Press, Waco,
TX. (The Second Princeton Symposium on Judaism and Christian Origins).

Van Aarde, A.G., 2011, 'Regeneration and resurrection in Matthew: Peasants in campo hearing time signals from scribes', Hervormde Teologiese Studies 67(3), Art. \#1012, 7 pages. http://dx.doi.org/10.4102/hts.v67i3.1012

VanderKam, J. \& Flint, P., 2002, The meaning of the Dead Sea Scrolls: Their significance for understanding the Bible, Judaism, Jesus, and Christianity, T\&T Clark, London \& New York.

Werman, C., 2009, 'A messiah in heaven?: A re-evaluation of Jewish and Christian apocalyptic traditions', in R.A. Clements \& D.R. Schwartz (eds.), Text, thought and practice in Qumran and early Christianity proceedings of the Ninth International Symposium of the Orion Center for the Study of the Dead Sea Scrolls and Associated Literature, jointly Sponsored by the Hebrew University Center for the Study of Christianity, 11-13 January 2004, pp. 281-299, Brill, Leiden \& Boston, MA. (Studies on the Texts of the Desert of Judah, 84).

Wise, M., Abegg, M. \& Cook, E. (with Gordon, N.), 2004, 'Serekh le'anshey haYahad', in D.W. Parry \& E. Tov (eds.), The Dead Sea Scrolls reader (Part 1): Texts concerned with religious law, pp. 21-43, Brill, Leiden \& Boston, MA.

Wright, R.B., 1985, 'Psalms of Solomon (First Century B.C.): A new translation and introduction', in J.H. Charlesworth (ed.), The Old Testament pseudepigrapha, vol. 2: Expansions of the 'Old Testament' and legends, wisdom and philosophical literature, prayers, psalms, and odes, fragments of lost Judea-Hellenistic works, pp. 639-670, Doubleday \& Company, Garden City, NY. 